\title{
Impact of Visual Merchandising on Consumer Behavior: A Study of Furniture Outlets
}

\author{
Neha P. Mehta ${ }^{1, *}$, Pawan Kumar Chugan ${ }^{2}$ \\ ${ }^{1}$ L. J. Institute of Management Studies, Ahmedabad, India \\ ${ }^{2}$ Institute of Management, Nirma University, Ahmedabad, India \\ *Corresponding Author: npmehta_9@yahoo.co.in
}

Copyright $@ 2014$ Horizon Research Publishing All rights reserved.

\begin{abstract}
In retail industry furniture and furnishing category has become more competitive. There are many players entering into organized format of retail in this category. Therefore, it becomes important for retailers to differentiate themselves from each other. As the products are similar, one of the area in which they can differentiate themselves is store presentation in terms of visual merchandising. To study which dimensions have an impact on purchase behavior of consumers, this study is undertaken. By analyzing the impact of various dimensions of merchandising display such as window display, store front, merchandise presentation, store layout and organization, creative style and trend co-ordination, signages/graphics and store environment, it is found that window display, store front, store layout and organization (shelf display) and creative style and trend co-ordination have impact on purchase behavior of consumers.
\end{abstract}

Keywords Visual Merchandising, Window Display, Store Front, Merchandise Display, Store Layout and Organization, Creative Style and Trend Co-Ordination, Signages/Graphics and Store Environment

\section{Introduction}

There is a dynamic change happening in the Indian retail market, where urbanization is increasing with increase in purchasing power of consumers. This rise in demand and consumers are getting more and more brand conscious. There are lots of changes happening in the retail industry of India from past one decade. Retail has been one of the growth areas in the global economy. It has witnessed a high growth rate in the developed countries, while for the emerging countries it is on exponential growth. India is one of the fastest growing retail market and Indian retail market is one of the top five countries in the world. In terms of population India is basically a young country. It has large youth population. Hence, it has conducive environment for growth of this sector. Indian retail market is expected to grow with the compounded annual growth rate of $18.8 \%$ by 2015 (Deloitte, 2012). The Indian retail industry is divided into organized and unorganized sectors. One of the major contributors is the modernized retail format i.e., "The Shopping Mall- the one stop destination". In India, retail industry contributes $20 \%$ of the GDP and $8 \%$ of the employment (FICCI, 2012). The Indian retail market is estimated at US\$ 450 billion (CCI, 2012). But organized retail is estimated at only US\$ 8 billion. There are about 300 new malls, 1,500 supermarkets and 325 departmental stores being built in the Indian cities very soon. Organized retail, which constitutes of $8 \%$ of total retail market, will continue to grow much faster such that will reach at the growth of $20 \%$ by 2020 . The current rank of India in global retail development index is $14^{\text {th }}$ which has slipped down by 9 ranks comparing to last year's rank (Kearney, 2013).

The key drivers for the immense growth in this sector are changing consumer profile and demographics, increase in the number of foreign brand available in the market, economic implications of the Government policies, increase in urbanization, credit availability, improvement in infrastructure, increasing investment in technology and real estate building a world class environment for the consumers. With the penetration of FDI retail industry in India is expected to grow by 15 to 20 percent in next five years (Kearney, 2012).

India's overall retail sector is expected to reach 1.3 trillion USD by 2020 . India stands $5^{\text {th }}$ in Global Retail Development Index (Kearney, 2012). Contribution of modern retail is maximum $8 \%$, in fashion and clothing segment it is $33 \%$ of the total retail sector. Annual rise in the demand of the readymade and western outfits is growing at $40-45 \%$. There are various other developments in apparel retailing like the manufacturing of private label is outsourced. The contribution of consumer durables $8 \%$ of the total retail sector. In furniture, retail market has shown modern retailers setting up home furnishing sections in the hypermarket or starting exclusive specialty store. It is giving a stiff competition to local retailers and carpenters. 


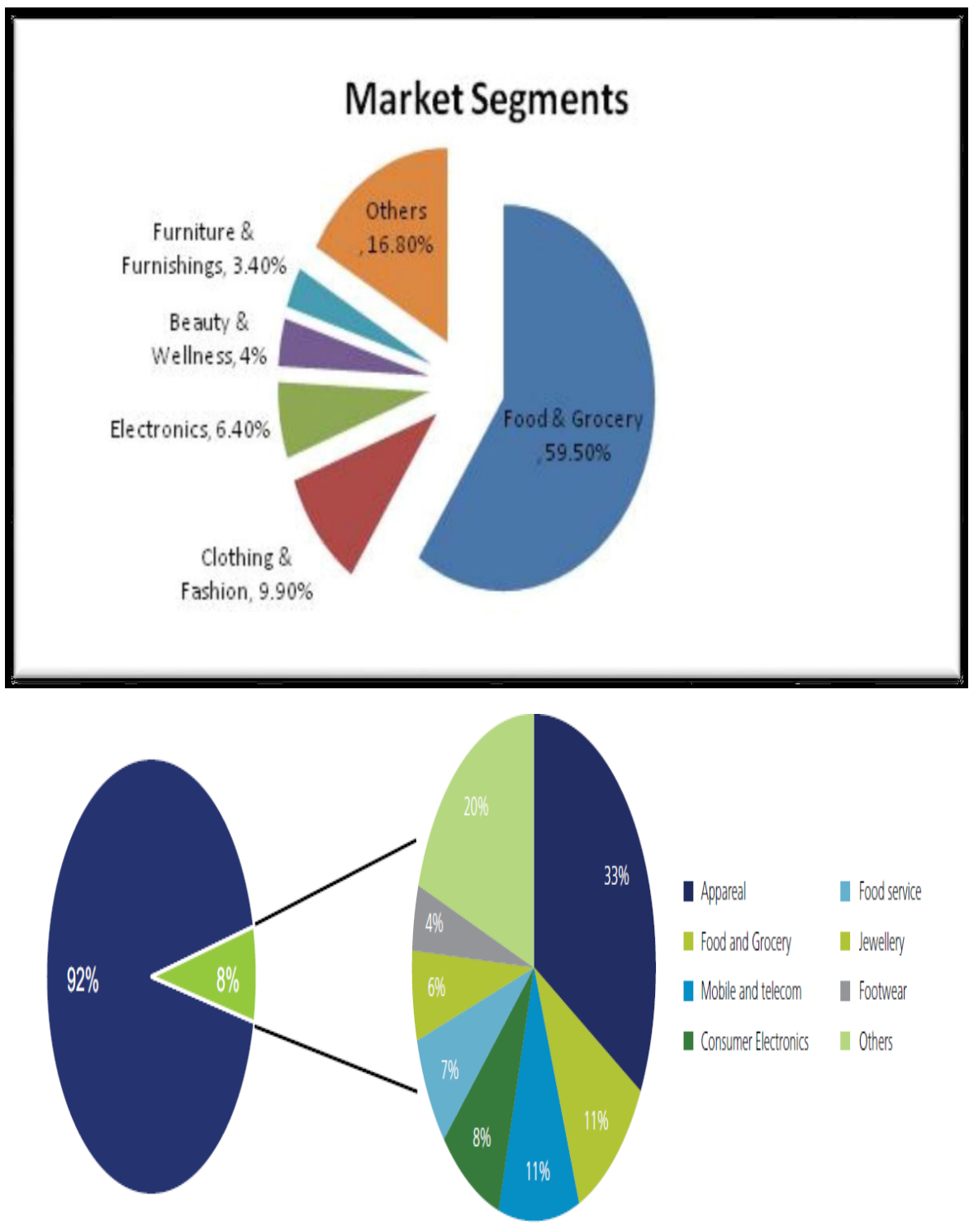

U Unorganized Retail

I Organized Retall

Figure 1. Source: Deloitte Retail POV, (2010), "Indian Retail Market: Changing with the changing times" Source: Deloitte Retail, (2013), "Indian Retail Market: Opening More Doors"

The sector is witnessing an influx of large domestic conglomerates such as Reliance Group, Future Group, AV Birla Group and international conglomerates such as Wal-Mart, Carrefour, and Tesco. With the liberalization of policies, Government of India have permitted $100 \%$ of FDI under single-brand product retailing, the competition in apparel retail market is going to increase. In November 2011, Government of India announced retail reforms for both multi-brand stores and single-brand stores. These market reforms paved the way for retail innovation and competition with multi-brand retailers such as Wal-Mart, Carrefour and Tesco, as well single brand majors such as IKEA, Nike and Apple. In current regime, Government approved reforms for single-brand stores welcoming anyone in the world to innovate in Indian retail market with $100 \%$ ownership. This development in retail creates fierce competition in the industry. Foreign retail chains entering India will aggravate the competition to different level. Hence, the retailers have to ensure that store appeals to the customers. In such case the retailers need to differentiate themselves from others. Due to FDI in retail, Indian consumers will be most benefited as they will get lifestyle products and experience of international standard (Chugan and Mehta, 2014).

The similarity of merchandise in the furniture segment forces the industry to utilize visual merchandising to improve the desirability of the product, differentiate their product and enhance the impulse buying behavior. Merchandising can create differential advantage to the 
retailers (Christiaans et al, 2009). Retail industry is changing rapidly than prior. Since the country is getting more competitive in terms of retail industry, visual merchandising is the only effective way of differentiating (Dabholkar, et al, 1996). The last thing a customer wants is similarity in merchandise. The innovation in store chain is very weak. Indian consumers are becoming more aware about the latest fashion and design and also in the innovation of the store space. They also want state of art products that have good quality and are of global standards and experience that also meets global standards. Visual merchandising or highest visual appeal is the only technique to create euphoria in retail industry by store presentation which should be successfully coordinated (Diamond and Diamond, 2007). There are various institutes in the country providing courses on visual merchandising. Retailers by incorporating innovative usage of store space can match the consumers' expectations and give strong competition. There is no longer a trend of typical store format/design. Hence, it becomes important to study visual merchandising in retail and help the marketers to understand the way they can differentiate themselves from competitors. This is done with the help of creative architects and designers along with visual merchandisers who creates a unique environment that has functional values.

\section{Review of Literature}

Visual merchandising or visual display is communicating the product retailers' wants to sell by effective presentation of the same which creates an impact on the customers in terms of their purchase and builds a positive image of store in customer's mind. It is the science of shopping that tells one ways to use those tools, ways to design signs that consumers will actually read and ways to make sure each message is in the appropriate place. It also tells one how to arrange display that consumer can find comfortably and easily, so that they can reach every part of the store easily (Underhill, 2009). "Visual merchandising is everything that customer sees both exterior and interior, that creates a positive image of the business and results in attention, interest, desire and action on the part of the customers (Passewitz, et al, 1991). Artistic role play a major role in creating an ambience which will in turn motivate customers for shopping (Diamond and Diamond, 2007). This may be the impact of various goods and services sold by the retailer which increases importance of retailing in marketing (Davies, et al, 2003, Passewitz, et al, 1991). "The purpose of visual merchandising is to educate the customer, to enhance the store/company's image, and to encourage multiple sales by showing apparel together with accessories" (Frings, 1999). It also highlights various criteria one must include regarding store set up which are eye-catching and also shows diverse merchandise (Garvey, 2010). The message is clearly conveyed to customers by effective signage and certain other significant aspects of arrangement. Products are introduced in style with colour by visual merchandising (Storms, 2006).
Visual merchandising is defined as "the presentation of a store/brand and its merchandise in a manner that will attract customers and motivates them to purchase through the teamwork of the store's advertising, display, special events, fashion coordination, and merchandising departments in order to sell the goods and services offered by the store/company" (Mills, et al, 1995, Diamond and Diamond, 2007). Retailers or organization tries to create and develop the image with the help of visual merchandising/visual presentation which appeals customers and transforms it in buying behavior and loyalty towards the retail outlet. This can be done by planning the merchandise that are to be featured and location they are supposed to be placed (Diamond and Diamond, 2007). Visual communications that are exposed to the customers in the retail outlet affects more than $80 \%$ to the other sensory organs and hence it is an efficient and inexpensive way of marketing than other means of communications (Tullman \& Clark, 2004). In modern retail, visual merchandising is a key to encourage a customer to purchase the products. This idea has always triggered purchase decision as an oldest merchandising strategy (Gopal, 2006). Retailers gradually realized that selling the product wasn't only important but the customers should also have satisfaction and convenience of shopping. One has to sell the product by selling the ambience too. Visual merchandising lures customers for shopping products with help of product display and shop's ambience (Iqbal et al, 2011). Stimulus in retailing includes space related, product related and people related aspects (Quartier, et al, 2008).

Window display is an important criterion of visual merchandising as it created first impression of the store on them (Mehta \& Chugan, 2012, Mehta \& Chugan, 2013). It attracts the customers inside the store (Bakarne, 2008).Like window display, store front also is the entry point of the customers which helps them decide whether to enter the store or not. So the arrangement of the merchandise in the store front should be impressive and it should motivate customers to enter (Schneider, et al, 2009). Signage is also an important aspect of visual merchandising; customers should be able purchase the product without any help of salesperson (Rook \& Hoch, 1985, Mehta \& Chugan, 2013).

Furniture plays a very important role in life of most of the people. It satisfies the social needs of the people. House of reflects the lifestyle, value and social status of an individual. Hence, shopping for furniture is also of most important. So retailers must try to attract the consumers to the store. Furniture and furnishing is a product category in which retailer should display the merchandise in such a way that customers get idea of arrangement of the same (Walters and White, 1987). Retailer must facilitate the consumer that caters them with their needs and wants like a market place. Home furniture retailers are fueling to the rise of competitive market through individual's lifestyle adaptation. In fact consumers are also becoming style and lifestyle conscious in terms of their home furniture and furnishing both. Retailer must also display the merchandise creatively so that they know new ways of arranging the merchandise and 
coordinating new trend, new color, etc, (Buchanan et al., 1999, Gajanayake, et al, 2011). Looking at the significant growth in the furniture industry, it is very important to create good visual merchandising and atmospherics. Visual merchandising and environment plays an important role in influencing store patronage. Store retailer must develop effective strategy to gain a competitive advantage. Furniture patronage is the extent to which a consumer who shops at furniture store once, the possibility of shopping is that he will visit same store next time and also the will to suggest it to others. It is important to study the perceptions of the consumers in terms of furniture merchandising, as there is limited research that has been done in the area.

Convenience of shopping, physical facilities (French, et al, 1972) or attributes, etc may influence buying decision of consumers. Environmental dimensions such as air quality, lighting, layout, carpeting, etc are also important (Engel, et al, 1995, Seock, 2013). Price, quality of merchandise, assortment, atmosphere, location, parking facility and sales people are important dimensions for a store (Bearden, 1978). Layout as a dimension of visual merchandising is important. It consists of space utilization, aisle planning and area arrangement (Banot and Wandebori, 2012). Apart from the above dimensions, another dimension that is important for furniture visual merchandising is creative/inspirational coordination (Seock, 2013). Merchandise assortment and price signage in terms of visual merchandising of furniture store is important as the products are higher priced (Seock, 2013).

\section{Research Methodology}

The research design is divided into two parts, the first part is exploratory in nature and the second part is descriptive. In the exploratory study the visual merchandiser and marketing manager of the mall were interviewed to understand and find the dimensions of visual merchandising. The study was intended to focus on the impact of visual merchandising in terms of furniture segment as a product category. The sample size of the research was 385. The sampling technique was mall intercept method, customer who walk out of the store were surveyed with the help of structured questionnaire. Thus, sampling procedure is purposive sampling. The survey was conducted in five furniture outlets viz Home Town, @ Home, Godrej Interio, Durian and Housefull, located in Ahmedabad city of Gujarat state in India. The dependent variable of study is purchase behavior (section 1in table 1) and independent variables are window display, store front, floor display, merchandising display, store layout and organization, creative style \& trend co-ordination, signage/graphics, and store environment (section 2 to 8 in table 1). These variables have individual constructs which are tested on five point Likert scale which ranged from never $=1$ to frequently $=5$. Since likert scale is a continuous scale, reliability test, factor analysis, correlation and step-wise linear regression have been run on the data for the study using SPSS.

\section{Research Hypothesis}

H1: Customer's purchases are influenced by window displays.

H2: Customer's purchases are influenced by store front.

H3: Customer's purchases are influenced by merchandising display.

H4: Customer's purchases are influenced by store layout and organization.

H5: Customer's purchases are influenced by Creative Style \& Trend Co-ordination.

H6: Customer's purchases are influenced by signage/graphics.

H7: Customer's purchases are influenced by store environment.

\section{Analysis and Findings}

Before performing analysis, normality of the data was checked in SPSS. There were 48 outliers in the data which were removed and the sample size of 385 became 337 . Thereafter, reliability test was carried out to find out if questionnaire is reliable or not. From the test result it was found that the cronbach alpha was 0.869 which means the questionnaire is reliable. After that factor analysis was carried out followed by correlation and regression analysis.

Since, section one and two (Table 1) have only one variables, hence, these sections are omitted from the factor analysis. Therefore, factor analysis starts from section three.

The KMO Bartlett's Test for all the sections is significant. Hence, factor analysis can be run on all the sections under test. The result of the principal component analysis for the third section of the survey, measuring store front, both items loaded in one component with an Eigen value of 1.783 and 89.145 is percentage of variance explained (Table 2). This result suggests that both questions (Table 2, question numbers 3 and 4) in this section were closely related and represented the same concept: customers influenced by store front. So for studying further correlation and regression analysis variable 3 is taken, as both variables have same value.

The result of the principal component analysis for fourth section of the survey, measuring influence of merchandising display, all four items loaded in one component with an Eigen value of 3.455 and 86.383 is percentage of variance explained (Table 2). This result suggests that all four questions (Table 2, question numbers 5-8) in this section were closely related and represented the same concept: customers influenced by merchandising display. But as "Merchandise is neatly arranged", this variable has highest value 0.947 , it is taken to study correlation and regression analysis. 
Table 1. Variables of Various Dimensions under Study with their References

\begin{tabular}{|c|c|}
\hline Variables of Dimension & References \\
\hline \multicolumn{2}{|l|}{ Section 1: Purchase Behavior } \\
\hline 1.I made a purchase from the store & Self Developed \\
\hline \multicolumn{2}{|l|}{ Section 2: Window Display } \\
\hline 2. Window display is so attractive that it leads customer into the store. & Bakarne, 2008 \\
\hline \multicolumn{2}{|l|}{ Section 3: Store Front } \\
\hline 3.Store front is attractive & \multirow{2}{*}{ Schneider, et al, 2009} \\
\hline 4.Store front motivates customers to enter the store & \\
\hline \multicolumn{2}{|l|}{ Section 4: Merchandise Display } \\
\hline 5. Merchandise arrangement is attractive. & \multirow{4}{*}{$\begin{array}{c}\text { 5, } 6 \text { (Davies and Ward, } \\
\text { 2002), 7, } 8 \text { (Walters and } \\
\text { White, 1987) }\end{array}$} \\
\hline 6. New items are presented noticeably to draw the customers' attention. & \\
\hline 7. Merchandise is neatly arranged. & \\
\hline 8. The store offers good variety of merchandise. & \\
\hline \multicolumn{2}{|l|}{ Section 5: Store Layout \& Organization } \\
\hline \multicolumn{2}{|l|}{ 9. Walking space in the store is not crowded. } \\
\hline $\begin{array}{l}\text { 10. The way through the store is well-structured so that consumers have no difficulty finding } \\
\text { their way. }\end{array}$ & \multirow{4}{*}{$\begin{array}{c}9,10 \text { (Banot and } \\
\text { Wandebori, 2012), 11, 12, } \\
13 \text { (Levy and Weitx, 1996) }\end{array}$} \\
\hline 11. Shelf space is appropriately occupied (proportionately arranged). & \\
\hline 12. Room setting arrangement or mock-ups is attractive. & \\
\hline 13. The store makes me feel like exploring it. & \\
\hline \multicolumn{2}{|l|}{ Section 6: Creative Style \& Trend Co-ordination } \\
\hline 14. The presentation of merchandise gives inspiration on how to furnish my own home. & \multirow{7}{*}{$\begin{array}{c}\text { 14, 18, 19, } 20 \text { (Seock, } \\
\text { 2013), } 17 \text { (Buchanan et al., } \\
\text { 1999), } 15,16 \text { (Gajanayake } \\
\text { et al, 2011) }\end{array}$} \\
\hline 15. Creative combinations of colors gives new design ideas for home. & \\
\hline 16. Color coordination creates an appealing store atmosphere. & \\
\hline 17. The presentation of merchandise is creative and unique. & \\
\hline 18. The store offers new idea for my home decoration or furnishings. & \\
\hline 19. The store displays newest styles of home furnishings. & \\
\hline 20. The store offers useful and accurate information about current trends and items. & \\
\hline \multicolumn{2}{|l|}{ Section 7: Signages/Graphics } \\
\hline 21. Signages of directions are so good that it does not require help of salesperson. & \multirow{5}{*}{$\begin{array}{c}\text { 21, 22, } 23 \text { (Seock, 2013), } \\
\text { 24, } 25 \text { (Rook \& Hoch, } \\
1985)\end{array}$} \\
\hline 22. Price tags are so good that it does not require help of salesperson. & \\
\hline 23. Signages are clearly visible. & \\
\hline 24. Discount or clearance items are displayed together in a specific area of the store. & \\
\hline 25. Signs clearly identify items on sale. & \\
\hline \multicolumn{2}{|l|}{ Section 8: Store Environment } \\
\hline 26. The store offers comfortable shopping environment. & \multirow{4}{*}{$\begin{aligned} 26,29 & \text { (Seock, 2013), 27, } 28 \\
& \text { (Kotler, 1974) }\end{aligned}$} \\
\hline 27. The store offers an enjoyable shopping environment. & \\
\hline 28. The store offers shopping ease. & \\
\hline 29. The store offers a pleasant shopping environment. & \\
\hline
\end{tabular}


Table 2. Factor Analysis

\begin{tabular}{|c|c|c|}
\hline Variables of Dimension & $\begin{array}{l}\text { KMO and } \\
\text { Bartlett's }\end{array}$ & Component \\
\hline \multicolumn{3}{|l|}{ Section 3: Store Front } \\
\hline 3.Store front is attractive & \multirow{2}{*}{0.500} & 0.944 \\
\hline 4.Store front motivates customers to enter the store & & 0.944 \\
\hline Component Eigen value & & 1.783 \\
\hline$\%$ of Variance Explained & & $89.145 \%$ \\
\hline \multicolumn{3}{|l|}{ Section 4: Merchandise Display } \\
\hline 5. Merchandise arrangement is attractive. & \multirow{4}{*}{0.841} & 0.921 \\
\hline 6. New items are presented noticeably to draw the customers' attention. & & 0.935 \\
\hline 7. Merchandise is neatly arranged. & & 0.947 \\
\hline 8. The store offers good variety of merchandise. & & 0.915 \\
\hline \multicolumn{2}{|l|}{ Component Eigen value } & 3.455 \\
\hline \multicolumn{2}{|l|}{$\%$ of Variance Explained } & 86.383 \\
\hline \multicolumn{3}{|l|}{ Section 5: Store Layout \& Organization } \\
\hline 9. Walking space in the store is not crowded. & \multirow{5}{*}{0.892} & 0.916 \\
\hline 10. The way through the store is well-structured so that consumers have no difficulty & & 0.945 \\
\hline 11. Shelf space is appropriately occupied (proportionately arranged). & & 0.948 \\
\hline 12. Room setting arrangement or mock-ups is attractive. & & 0.941 \\
\hline 13. The store makes me feel like exploring it. & & 0.917 \\
\hline \multicolumn{2}{|l|}{ Component Eigen value } & 4.355 \\
\hline \multicolumn{2}{|l|}{$\%$ of Variance Explained } & 87.107 \\
\hline \multicolumn{3}{|l|}{ Section 6: Creative Style \& Trend Co-ordination } \\
\hline 14. The presentation of merchandise gives inspiration on how to furnish my own home. & \multirow{7}{*}{0.896} & 0.890 \\
\hline 15. Creative combinations of colors gives new design ideas for home. & & 0.905 \\
\hline 16. Color coordination creates an appealing store atmosphere. & & 0.899 \\
\hline 17. The presentation of merchandise is creative and unique. & & 0.878 \\
\hline 18. The store offers new idea for my home decoration or furnishings. & & 0.858 \\
\hline 19. The store displays newest styles of home furnishings. & & 0.881 \\
\hline 20. The store offers useful and accurate information about current trends and items. & & 0.870 \\
\hline \multicolumn{2}{|l|}{ Component Eigen value } & 5.460 \\
\hline \multicolumn{2}{|l|}{$\%$ of Variance Explained } & $78.006 \%$ \\
\hline \multicolumn{3}{|l|}{ Section 7: Signage/Graphics } \\
\hline 21. Signage of directions is so good that it does not require help of salesperson. & 0.897 & 0.903 \\
\hline 22. Price tags are so good that it does not require help of salesperson. & & 0.945 \\
\hline 23. Signage is clearly visible. & & 0.929 \\
\hline 24. Discount or clearance items are displayed together in a specific area of the store. & & 0.922 \\
\hline 25 . Signs clearly identify items on sale. & & 0.908 \\
\hline \multicolumn{2}{|l|}{ Component Eigen value } & 4.245 \\
\hline \multicolumn{2}{|l|}{$\%$ of Variance Explained } & $84.895 \%$ \\
\hline \multicolumn{3}{|l|}{ Section 8: Store Environment } \\
\hline 26. The store offers comfortable shopping environment. & 0.868 & 0.942 \\
\hline 27. The store offers an enjoyable shopping environment. & & 0.947 \\
\hline 28. The store offers shopping ease. & & 0.960 \\
\hline 29. The store offers a pleasant shopping environment. & & 0.956 \\
\hline \multicolumn{2}{|l|}{ Component Eigen value } & 3.617 \\
\hline \multicolumn{2}{|l|}{$\%$ of Variance Explained } & $90.427 \%$ \\
\hline
\end{tabular}


The principal component analysis for the fifth section, measuring store layout \& organization, resulted in one component with an Eigen value of 4.355 accounting 87.107 of percentage of variance explained (Table 2). This component consisted of five questions. These five questions (Table 2, question numbers 9-13) were closely related representing the same concept: customer buying behavior influenced by store layout \& organization. But as "Shelf space is appropriately occupied" has the highest value 0.948 , it is taken to study correlation and regression analysis.

The principal component analysis for the sixth section, measuring creative style \& trend co-ordination, resulted in one component with an Eigen value of 5.460 accounting 78.006 of percentage of variance explained variance (Table 2 ). This component consisted of seven questions. These seven questions (Table 2, question numbers 14-20) were closely related representing the same concept: customer buying behavior influenced by creative style \& trend co-ordination. But as "Creative combinations of colors give new design ideas for home" has the highest value 0.905 , it is taken to study correlation and regression analysis.

The principal component analysis for the seventh section, measuring influence of signage/graphics, resulted in one component with an Eigen value of 4.245 accounting 84.895 of percentage of variance explained variance (Table 2). This component consisted of five questions. These five questions (Table 2, question numbers 21-25) were closely related representing the same concept: customer buying behavior influenced by signage/graphics. But as "Price tags are so good that it does not require help of salesperson" has the highest value 0.945 , it is taken to study correlation and regression analysis.

The principal component analysis for the eighth section, measuring influence of store environment, resulted in one component with an Eigen value of 3.617 accounting 90.427 of percentage of variance explained variance (Table 2). This component consisted of four questions. These four questions (Table 2, question numbers 26-29) were closely related representing the same concept: customer buying behavior influenced by store environment. But as "Store offers shopping ease" has the highest value 0.960 , it is taken to study correlation and regression analysis.

For Model 1, $\mathrm{R}^{2}$ value for window display is 0.551 (Table 4) which is somewhat close to 1 . If the value of $R^{2}$ is 1 or reaches one proves that the variables have strong correlation and if $r$ square value is 0 or nears 0 it means that the variables have no or weak correlation. $\mathrm{R}^{2}$ value for store front also is 0.610 (model 2, Table 4) which is moderately close to $1 . \mathrm{R}^{2}$ value for merchandise display also is 0.642 (model 3, Table 4) which is again moderately close to $1 . \mathrm{R}^{2}$ value for creative style and trend co-ordination also is 0.645 (model 4, Table 4), this is also moderately close to 1 . As all the four variables i.e. window display, store front, merchandise display and creative style and co-ordination are somewhat or moderately found close to 1 , they have good and significant relationship with purchasing behavior of customers.

H1: Customer's purchases are influenced by window displays.

In the result of a Pearson correlation test, a significant correlation was shown between buying behavior and window display with a p-value less than .000 (Table 3). Since the $\mathrm{p}$-value $(\mathrm{p}<0.05)$ data provided sufficient evidence that window display was significantly related with customers' impulse buying behavior in terms of correlation analysis. In stepwise linear regression analysis also it is found that window display significantly influence customers' buying behavior (Table 5) along with Pearson correlation test showed the significant relationship between buying behavior and window display (Table 3 ). This suggested that there was a directional relationship, where window display significantly influenced customers' buying behavior. The data provides sufficient evidence that there was a significant relationship between customers' buying behavior and window display. The equation of the regression model will be $y=0.653+0.790$ (Window display attractive leads into the store)

This result might have come from the fact that window display was also significantly correlated with other variables including the variables (i.e., store front, shelf space and creative combination) that had the stronger relationship with buying behavior from the regression analysis; the significant relationship with buying behavior shown from the a simple bivariate analysis might have resulted from the significant relationship with these variables. The result showed the window display has significant influence on customers' actual buying decision in a direct way; it may play a role to attract customers' to enter the store by creating attractiveness of a store (Darden et al., 1983), which may ultimately contribute their impulse buying. Hence, first hypothesis is proved that customer's purchases are influenced by window displays.

Table 3. Correlation with Purchase Behavior

\begin{tabular}{|c|c|c|}
\hline Variables & Pearson Coefficient & Significance (p) \\
\hline Window Display & 0.743 & 0.000 \\
\hline Store Front & 0.727 & 0.000 \\
\hline Merchandise Display (Merchandise are neatly arranged) & 0.572 & 0.000 \\
\hline Store Layout and Organization (Shelf Space) & 0.596 & 0.000 \\
\hline Creative Style \& Trend Co-ordination (Creative Combination) & 0.463 & 0.000 \\
\hline Signages/Graphics (Signages of Price Tags) & 0.476 & 0.000 \\
\hline Store Environment (Shopping Ease) & 0.449 & 0.000 \\
\hline
\end{tabular}


Table 4. Model Summary of Step-wise Regression Analysis

\begin{tabular}{|c|c|c|c|c|}
\hline Model & $\mathrm{R}$ & $\mathrm{R}^{2}$ & Adjusted $\mathrm{R}^{2}$ & Std. Error of the Estimate \\
\hline 1 & $.743^{\mathrm{a}}$ & .551 & .550 & .57830 \\
\hline 2 & $.781^{\mathrm{b}}$ & .610 & .608 & .54002 \\
\hline 3 & $.801^{\mathrm{c}}$ & .642 & .639 & .51806 \\
\hline 4 & $.806^{\mathrm{d}}$ & .649 & .645 & .51372 \\
\hline
\end{tabular}

a. Predictors: (Constant), Window display attractive leads into the store

b. Predictors: (Constant), Window display attractive leads into the store, Store front are attractive

c. Predictors: (Constant), Window display attractive leads into the store, Store front are attractive, Shelf space is appropriately occupied d. Predictors: (Constant), Window display attractive leads into the store, Store front are attractive, Shelf space is appropriately occupied, Creative combination of colors give me a new design ideas for home

Table 5. Coefficients of Step-wise Regression Analysis

\begin{tabular}{|c|c|c|c|c|}
\hline Model & & $\mathrm{B}$ & $\mathrm{t}$ & Sig. \\
\hline \multirow{3}{*}{1} & (Constant) & .653 & 4.480 & .000 \\
\cline { 2 - 5 } & Window display attractive leads into the store & .790 & 20.290 & .000 \\
\hline \multirow{3}{*}{2} & (Constant) & .257 & 1.746 & .082 \\
\cline { 2 - 5 } & Window display attractive leads into the store & .478 & 8.365 & .000 \\
\cline { 2 - 5 } & Store front are attractive & .416 & 7.084 & .000 \\
\hline \multirow{3}{*}{3} & (Constant) & -.023 & -.150 & .881 \\
\cline { 2 - 5 } & Window display attractive leads into the store & .415 & 7.411 & .000 \\
\cline { 2 - 5 } & Store front are attractive & .333 & 5.718 & .000 \\
\hline \multirow{3}{*}{4} & Shelf space is appropriately occupied & .213 & 5.469 & .000 \\
\cline { 2 - 5 } & (Constant) & .098 & .629 & .530 \\
\cline { 2 - 5 } & Window display attractive leads into the store & .421 & 7.564 & .000 \\
\cline { 2 - 5 } & Store front are attractive & .374 & 6.242 & .000 \\
\cline { 2 - 5 } & Shelf space is appropriately occupied & .262 & 6.086 & .000 \\
\cline { 2 - 5 } & Creative combination of colors give me a new design ideas for home & -.123 & -2.579 & .010 \\
\hline
\end{tabular}

Table 6. Excluded Variables Regression Analysis

\begin{tabular}{|c|c|c|c|c|}
\hline Model & Variables & Beta In & $\mathrm{t}$ & Sig. \\
\hline \multirow{6}{*}{1} & Store front are attractive & $.380^{\mathrm{b}}$ & 7.084 & .000 \\
\hline & Merchandise are neatly arranged & $.169^{\mathrm{b}}$ & 3.634 & .000 \\
\hline & Shelf space is appropriately occupied & $.279^{\mathrm{b}}$ & 6.874 & .000 \\
\hline & Creative combination of colors give me a new design ideas for home & $.104^{\mathrm{b}}$ & 2.444 & .015 \\
\hline & Price tags are so good that it does not require help of salesperson & $.126^{\mathrm{b}}$ & 2.992 & .003 \\
\hline & The store offer shopping ease & $.135^{\mathrm{b}}$ & 3.316 & .001 \\
\hline \multirow{5}{*}{2} & Merchandise are neatly arranged & $.088^{\mathrm{c}}$ & 1.928 & .055 \\
\hline & Shelf space is appropriately occupied & $.220^{\mathrm{c}}$ & 5.469 & .000 \\
\hline & Creative combination of colors give me a new design ideas for home & $.006^{\mathrm{c}}$ & .135 & .893 \\
\hline & Price tags are so good that it does not require help of salesperson & $.087^{\mathrm{c}}$ & 2.169 & .031 \\
\hline & The store offer shopping ease & $.082^{\mathrm{c}}$ & 2.086 & .038 \\
\hline \multirow{4}{*}{3} & Merchandise are neatly arranged & $-.030^{\mathrm{d}}$ & -.596 & .552 \\
\hline & Creative combination of colors give me a new design ideas for home & $-.117^{\mathrm{d}}$ & -2.579 & .010 \\
\hline & Price tags are so good that it does not require help of salesperson & $-.005^{\mathrm{d}}$ & -.109 & .913 \\
\hline & The store offer shopping ease & $-.006^{\mathrm{d}}$ & -.151 & .880 \\
\hline \multirow{3}{*}{4} & Merchandise are neatly arranged & $.010^{\mathrm{e}}$ & .190 & .850 \\
\hline & Price tags are so good that it does not require help of salesperson & $.039^{\mathrm{b}}$ & .860 & .390 \\
\hline & The store offer shopping ease & $.044^{\mathrm{b}}$ & .982 & .327 \\
\hline
\end{tabular}


H2: Customer's purchases are influenced by store front.

In the result of a Pearson correlation test, a significant correlation was shown between buying behavior and store front with a p-value less than .005 (Table 3$)$. Since the $(\mathrm{p}<.05)$ for second hypothesis, suggesting there is significant correlation between buying behavior and store front. The data provided sufficient evidence that store front was significantly related to customers' buying behavior. In consistence with the result of the correlation test, the stepwise linear regression analysis found that store front also significantly influence customers' buying behavior (Table 5). This result suggests that store front significantly influence customers' buying behavior. Hence, second hypothesis is proved that customer's purchases are influenced by store front. The equation of the regression model will be $y=0.257$ +0.478 (Window display attractive leads into the store) +0.416 (Store front are attractive). Hence, second hypothesis is proved, customer's purchases are influenced by store front.

H3: Customer's purchases are influenced by merchandising display.

The result of a Pearson correlation test found that there is correlation between buying behavior and merchandising display (Table 3 ). The significance value was less than 0.05 suggesting that the data provided sufficient evidence that merchandise display is significantly related with customers' buying behavior. But, stepwise linear regression analysis did not show a significant relationship between buying behavior and merchandising display as it is present in the excluded variables table (Table 6), this suggests that merchandise display did not significantly influence customer's buying behavior. Hence, third hypothesis is rejected; customer's purchases are influenced by merchandise display.

H4: Customer's purchases are influenced by store layout and organization (Shelf Space).

A Pearson correlation test found a significant correlation between buying behavior and store layout and organization (shelf space) with a p-value 0.000 (Table 3 ). Because the significance value is smaller than 0.05 , the result suggested that the data provided sufficient evidence that store layout and organization (shelf space) was significantly related with customers' buying behavior. Stepwise linear regression analysis findings showed that store layout and organization (shelf space) significantly influenced customers' buying behavior (Table 5). This result suggests that store layout and organization (shelf space) significantly influenced customers' buying behavior. The equation of the regression model will be $y=-0.023+0.415$ (Window display attractive leads into the store) +0.333 (Store front are attractive) +0.213 (Shelf space is appropriately occupied). Hence, fourth hypothesis is selected; customer's purchases are influenced by store layout and organization.

H5: Customer's purchases are influenced by creative style $\&$ trend co-ordination.

The result of a Pearson correlation test found that there is no significant correlation between buying behavior and creative style \& trend co-ordination (Table 3). The significance value was less than 0.05 suggesting that the data provided sufficient evidence that creative style \& trend co-ordination is significantly related with customers' buying behavior. As, the Pearson correlation test show a significant relationship between buying behavior and creative style \& trend co-ordination (Table 5), the regression analysis also suggested that the creative style $\&$ trend co-ordination is significantly influence customers' buying behavior. $\mathrm{R}^{2}$ value for creative style and trend co-ordination also is 0.645 (model 4, Table 4) which is close to 1 . If the value of $\mathrm{R}^{2}$ is 1 or reaches one proves that the variables have strong correlation and if $r$ square value is 0 or nears 0 it means that the variables have no or weak correlation. The data provides sufficient evidence that there was significant directional relationship between customers' buying behavior and creative style $\&$ trend co-ordination. The equation of the regression model will be $\mathrm{y}=0.098+0.421$ (Window display attractive leads into the store) +0.374 (Store front are attractive) +0.262 (Shelf space is appropriately occupied) + -0.123 (Creative combinations of colors gives me new ideas for home). Hence, fifth hypothesis is selected; customer's purchases are influenced by creative style and trend co-ordination.

H6: Customer's purchases are influenced by signage/graphics.

A Pearson correlation test found a significant correlation between buying behavior and signage/graphics with a $\mathrm{p}$-value less than 0.000 (Table 3). Because the significance value is smaller than 0.05 , the result suggested that the data provided sufficient evidence that signage/graphics was significantly related with customers' buying behavior. But, the stepwise linear regression analysis did not find that signage/graphics significantly influenced customers' buying behavior as the variable is found present in the table of excluded variables (Table 6). This result suggests that signage/graphics did not significantly influenced customers' buying behavior. Hence, sixth hypothesis is rejected; customer's purchases are influenced by signage/graphics.

H7: Customer's purchases are influenced by store environment.

A Pearson correlation test found a significant correlation between buying behavior and store environment with a p-value less than 0.000 (Table 3). Because the significance value is smaller than 0.05 , the result suggested that the data provided sufficient evidence that store environment was significantly related with customers' buying behavior. But, the regression analysis did not find that store environment significantly influenced customers' buying behavior as the variable is excluded from the table (Table 6). This result suggests that store environment did not significantly influenced customers' buying behavior. Hence, seventh hypothesis is rejected; customer's purchases are influenced by store environment. 


\section{Conclusion and Implication}

Furniture and furnishing is contributing 3.4 per cent of revenue to retail industry (Deloitte, 2011). This segment is growing with many organized players entering the competition nationally and from across borders. In such situation it becomes as discussed previously for the retailers to differentiate themselves from other. From the analysis it is found that window display, store front, store layout and organization (shelf space) and Creative combination of colors give me a new design idea for home are significantly related to the purchase behavior of the customers. Since, the $\mathrm{R}^{2}$ value of above mentioned variables are also close to 1 (Table 4), there is a good relationship of these variables with purchase behavior. The variables being merchandise display, signage/graphics and store environment do not have relationship with purchase behavior. Hence, consumers do not find these variables impacting their purchase behavior. Store front impacts the purchase behavior in terms of furniture and electronics product category. They are the first impression of store which attracts customers to visit the store. It also sets an impression of what type of merchandise are available in the store. Retailers or marketers should make window display and store front creative and attractive. It should not be cluttered and confusing. Merchandise that are displayed in store window and store front should be changed twice in month at least to keep these two aspects live and fresh. Also window and store front should be neat and tidy and lightings should be appropriate. In terms of merchandise display, it should be arranged neatly and in proper order so that customer's feels attracted towards buying. The product displayed in shelf in terms of furniture and electronics category should be dusted regularly, shelf should be cleaned regularly and these products should be arranged at the eye reaching distance. Also the products should be arranged in such a way that walking space is not crowded and way through the store is well structured. In furniture outlets as the display happens according to type of room, retailer must take care of colour combination for a room; accessories also should be arranged according that it gels with room setting. From this arrangement consumers must get new ideas of furnishing their home too. The store should display latest style of merchandise which is in current trend. Signages should be self explanatory so that consumers do not require assistance of the salesperson. The font type and size should be such that it is properly visible to all consumers. Store environment also should be soothing which helps customers stay for long time in the store. The store must not stink, it should be clean, there should be light music playing in the store and it should be comfortable. This will help the variables that are excluded to become strong and also impact the purchase of customers.

Furniture and furnishing products are though not purchased mostly on impulse, but still certain cues of visual stimuli definitely has impact on the purchase behavior. It positively helps customer in buying and feeling about the product buying urge. This proves that visual merchandising helps in instigating purchase desire. Marketers must effectively use the variables that have correlation with purchase behavior and make them stronger so that the sales of store can be increased. The variables that are not found significantly correlated, marketers must do necessary alterations in it and make strong so that it also impacts the sales. Window display and store front must have best of product offerings store has so that customers get attracted by it and footfalls are increased inside the store. Merchandise display should be neat and fresh. It should not be shabby which gives negative impact on the customers. Store layout and organization must also be well arranged and shelf display should be in reach of the customer's eye. Hence, if a marketer adopts all the criteria of visual merchandising into practice it will help them to stand apart.

\section{REFERENCES}

[1] Banot, A. and Wandebori, H. (2012), "Store Design and Store Atmosphere Effect on Customer Sales per Visit." 2nd International Conference on Business Economics, Management and Behavioral Sciences. Pp. 84-89.

[2] Bakarne, S. (2008), "Visual Merchandising Concept." 111Articles.info, http://www.111 articles.info/business/small-business/visualmerchandising-concepts.html. accessed on 12/03/2012.

[3] Bearden, W. (1978), Media usage, psychographics and demographic dimensions of retail shoppers. Journal of retailing pp. 54:65-74.

[4] Buchanan, C. Simmons, C. J. and Bickart, B. A. (1999), "Brand Equity Dilution: Retailer Display and Context Brand Effects", Journal of Marketing Research, Vol.36 No. 3, pp. 345.

[5] CCI, (2012), “A Report on Indian Retail Industry", www.cci.gov.in/images/media/ResearchReports/Apparel.pdf, accessed on 18/3/2013.

[6] Christiaans, H. Quartier, K. Cleempoel, K. (2009), "Retail Design: Lighting as an Atmospheric Tool, Creating Experiences Which Influence Consumers' Mood and Behaviour in Commercial Spaces, Undisciplined!” Design Research Society Conference, Sheffield Hallam University, UK.

[7] Chugan, Pawan K. and Mehta, N. (2014), "FDI in Retail Sector: The Implications and Challenges", Emerging Paradigms in Corporate Finance and Regulatory Framework, Conference Proceeding Book, Rijwani, P. \& Amarnani, N NICOM 2014, India, pp. 339-354, http://papers.ssrn.com/sol3/papers.cfm?abstract_id=2384576

[8] Dabholkar, P. A. Thorpe, D. I. and Rentz, J. O. (1996), “A Measure of Service Quality for Retail Stores: Scale Development and Validation", Journal of the Academy of Marketing Science, 24(1), pp. 3-16.

[9] Darden, W.R. Erdem,O. \& Darden, D.K. (1983), “A Comparison and Test of Three Casual Models of Patronage Intentions", Patronge Behavior and Retail Management, New 
York, NY: North Holland.

[10] Davies, B. and Ward, P. (2002), "Managing Retail Consumption", Wiley, London.

[11] Davies, B. Kerfoot, S. \& Ward, P. (2003), "Visual Merchandising and Creation of Discernible Retail Brands", International Journal of Retail \& Distribution Management. Vol. 31, No. 3, pp. 143-152.

[12] Deloitte, (2010), Indian Retail Market: Changing with the Changing Times, www.deloitte.com/in, accessed on 10/10/2013.

[13] Deloitte, (2011), "Indian Retail Market: Embracing a New Trajectory",

www.deloitte.com/assets/Dcom-India/.../Indian_Retail_Mark et.pdf, accessed on 15/3/2012.

[14] Deloitte, (2013), Indian Retail Market: Opening More Doors, www.deloitte.com/in, accessed on 15/2/2013.

[15] Diamond, E. \& Diamond, J. (2007), "The Visual Merchandising Concept in a Contemporary Environment", 4th Edition, Prentice Hall.

[16] Engel, J. F. Blackwell, R. D. Miniard, P. W. (1995), Consumer Behavior, 8th edition, Dryden Press, Orlando.

[17] FICCI, (2012), “The Indian Kaleidoscope Emerging Trends in Retail",

www.pwc.in/en_IN/in/assets/pdfs/.../retail-and.../retail-report -300812.pdf, accessed on 18/3/2013.

[18] French,N.D. Williams J.J. and Chase, W.A.(1972), "A Shopping Experiment on Price Quality Relationships." Journal of Retailing 48:3

[19] Frings, G.S., (1999), Fashion: From concept to customer (6th ed). Upper Saddle River, New Jersey: Prentice-Hall.

[20] Gajanayake, R. Gajanayake, S. Surangi, H., (2011), "The Impact of Selected Visual Merchandising Techniques on Patronage Intentions in Supermarkets", 2nd International Conference on Business and Economic Research Proceedings.

[21] Garvey, J. P. (2010), "All About Visual Merchandising”, retrieved from

http://ezineartivles.com/?All-About-Visual-Merchandising\& $\mathrm{id}=3598781$, on $11 / 10 / 2011$.

[22] Gopal, V. (2006), Visual Merchandising: An Introduction, ICFAI University Press, 4-5.

[23] Iqbal, A. Umer, H. Maqbool, A. Sunil, N., Pillai, K. (2011), "Design, Effectiveness and Role of Visual Merchandising in Creating Customer Appeal", MPRA Paper No. 30365.

[24] Kearney, A. T. (2012), Retail Global Expansion: A Portfolio of Opportunities, http://www.atkearney.com/documents/101 92/3903b4b7-265c-484e-932c-50169e5aa2f3, accessed on $10 / 10 / 2013$.

[25] Kearney, A. T. (2013), The 2013 Global Retail Development Index Global Retailers: Cautiously Aggressive or Aggressively Cautious? http://www.atkearney.com/consumer-products-retail/global-r etail-development-index/full-report/-/asset_publisher/oPFrG $\mathrm{kbIkz0Q/content/2013-global-retail-development-index/101}$ 92 , accessed on $10 / 10 / 2013$.

[26] Kotler, P. (1974), "Atmospherics as a Marketing Tool", Journal of Retailing, vol.49, pp.48-64.

[27] Levy, M. and Weitz, B. A. (1996), Essentials of Retailing, Irwin, Chicago, IL.

[28] Mehta, N. \& Chugan, Pawan K. (2012), "Visual Merchandising: Impact on Consumer Behavior (An Exploratory Study of Apparel Segment in Ahmedabad City)," Mapping the Global Future: Evolution Through Innovation and Excellence, Reading Book, Delener, N. Fuxman, L. Lu, F. V. \& Rodrigues, S., Global Business and Technology Association, Fourteenth Annual International Conference, New York pp. 607-614,http://papers.ssrn.com/sol3/papers.cf m?abstract_id $=2217487$

[29] Mehta, N., \& Chugan, Pawan K. (2013), "The Impact of Visual Merchandising on Impulse Buying Behavior of Consumers: A Case from Central Mall of Ahmedabad India," Universal Journal of Management 1(2), pp. 76-82. http://papers.ssrn.com/sol3/papers.cfm?abstract_id=2355742

[30] Mills, K.H., Paul, J.E. \& Moorman, K.B., (1995), “Applied visual merchandising" (3rd ed.). Englewood Cliffs, New Jersey: Prentice-Hall.

[31] Passewitz, G. Stoop, H. Zetocha, D., (1991), "Visual Merchandising: A Guide for Small Retailers". Ames: Iowa State University.

[32] Quartier, K. Vanrie, J. \& Koenraad, V. C. (2008), “The Interaction Between Interpreted Space, Mood and Behavior in Retail Environments: A Conceptual Research Model", EDRA Conference, Mexico, pp 2-4.

[33] Rook, D.W. \& Hoch, S.J. (1985), "Consuming impulses", Advances in Consumer Research, 12, pp. 23-7.

[34] Schneider, F. Kimbrell, G. Woloszyk, C. (2009), Marketing Essentials, Woodland Hills: The McGraw-Hill Companies.

[35] Seock, Y. K., (2013), "Understanding the Importance of Visual Merchandising on Store Image and Shopper Behaviors in Home Furnishings Retail Setting." European Journal of Business and Management, vol. 5, no. 4, pp. 174-187.

[36] Storms, R. (2006), "An outline of Visual Merchandising" retrieved from http://www.articlesbase.com/recruitment-artic les/an-outline-of-visual-merchandising-2720346.html, on $11 / 10 / 2011$.

[37] Tullman M. L. \& Clark, R. K., (2004), "Revitalizing Visual Merchandising-Restoring Balance to Retail Environment Entails Engaging all Five Senses", pp. 1-2.

[38] Underhill, P. (2009), "Why We Buy: The Science of Shopping", Simon \& Schuster, New York.

[39] Walters, D and White, D., (1987), "Retail Marketing Management”, Basingstock: Macmillan Press 